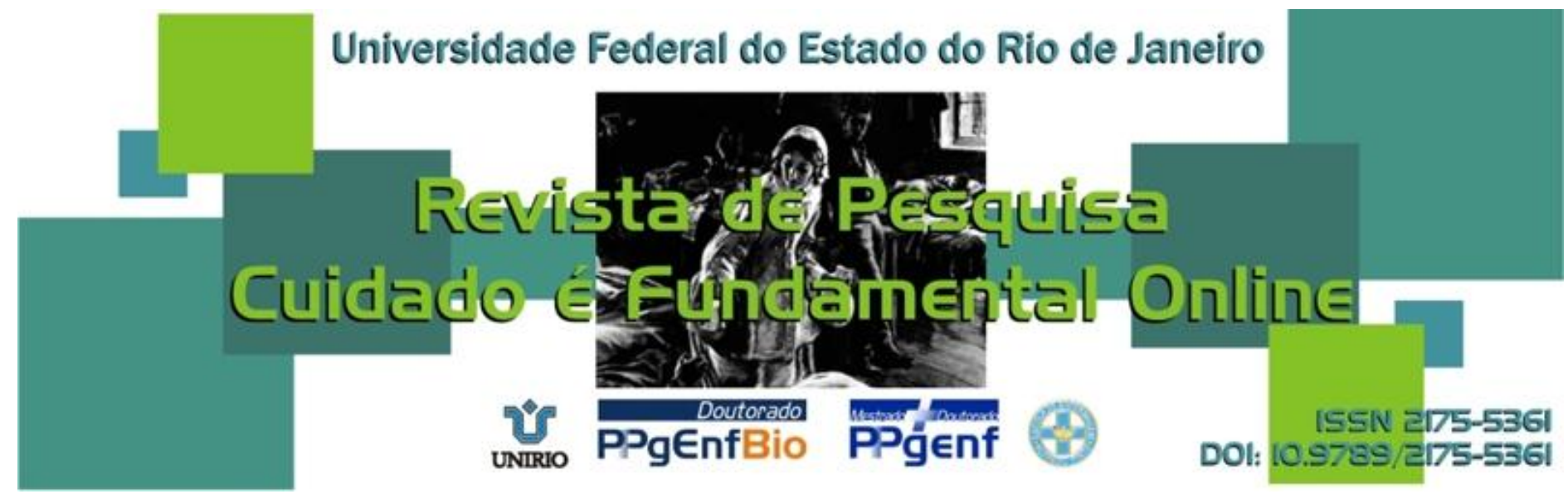

\title{
RESEARCH
}

\section{SOCIAL SUPPORT NETWORK TO OLDER PEOPLE WITH DEPRESSIVE SYMPTOMS IN A MUNICIPALITY OF NORTHEAST IN BRAZIL}

\section{REDE DE SUPORTE SOCIAL A PESSOAS IDOSAS COM SINTOMAS DEPRESSIVOS EM UM MUNICÍPIO DO NORDESTE BRASILEIRO}

\section{RED DE APOYO SOCIAL A PERSONAS MAYORES CON SÍNTOMAS DEPRESIVOS EN UN MUNICIPIO DEL NORDESTE DE BRASIL}

Marta dos Reis Alves ${ }^{1}$, Alba Benemérita Alves Vilela ${ }^{2}$, Andréa dos Santos Souza ${ }^{3}$, Doane Martins da Silva ${ }^{4}$, Edméia Campos Meira $^{5}$, Aline Cristiane de Souza Azevedo Aguiar ${ }^{6}$

\begin{abstract}
Objective: Describe the sociodemographic profile of older people with depressive symptoms and their social support structure regarding the size, composition and degree of the elderly proximity with the network components. Method: Descriptive, transversal and quantitative study, conducted with 88 elderly, being used for data collection the Short Geriatric Depression Scale, Minimum Map of Social Relations and a form composed by sociodemographic questions. Results: Predominated older people the female sex, aged 60 to 69 years, low income and education. 807 people were cited by the elderly to compose their social support network, with prevalence of intimate relationships and family members. Conclusion: The identification of social support enables health professionals to work in a partnership with it in order to promote a better quality of life of elderly. Descriptors: Elderly, Depression, Social Network.
\end{abstract}

\section{RESUMO}

Objetivo: Descrever o perfil sociodemográfico de pessoas idosas com sintomas depressivos e a estrutura de sua rede de suporte social quanto a tamanho, composição e grau de proximidade do idoso com os componentes da rede. Métodos: Estudo descritivo, transversal e quantitativo, realizado com 88 idosos, sendo utilizados para a coleta de dados a Escala de Depressão Geriátrica Abreviada, o Mapa Mínimo de Relações Sociais e um formulário constituído de questões sociodemográficas. Resultados: Predominaram pessoas idosas do sexo feminino, faixa etária de 60 a 69 anos, baixo nível de renda e escolaridade. Foram citadas 807 pessoas pelos idosos para compor sua rede de suporte social, havendo prevalência das relações íntimas e de pessoas da família. Conclusão: A identificação da rede de suporte social permite aos profissionais de saúde atuar em parceria com a mesma, no intuito de promover uma melhor qualidade de vida do idoso. Descritores: Idoso, Depressão, Rede Social.

\section{RESUMEN}

Objetivo: Describir el perfil sociodemográfico de las personas mayores con síntomas depresivos y la estructura de su red apoyo social en relación con el tamaño, composición y grado de proximidad de los ancianos con los componentes de la red. Método: Estudio descriptivo, transversal y cuantitativo, realizado como 88 ancianos, siendo utilizado para la recolección de datos la Escala de Depresión Geriátrica Corta, Mapa Mínima de Relaciones Sociales y formulario que consta de cuestiones sociodemográficas. Resultados: Predominaron las personas mayores de los sexo femenino, con edades entre 60 y 69 años, bajos niveles de renta y escolaridad. 807 personas fueron citadas por los ancianos para componer su red de apoyo social, con predominio de las relaciones íntimas y miembros de la familia. Conclusión: La identificación de la red de apoyo social permite a los profesionales de la salud trabajar en asociación con la misma a fin de promover una mejor calidad de vida de los ancianos. Descriptores: Anciano, Depresión, Red Social.

\footnotetext{
${ }^{1}$ Nurse, Student of Master's of the Post-graduate Program in Nursing and Health of the State University of Southwest Bahia. Scholarship Student of the Foundation for Research Support of the State of Bahia (FAPESB). E-mail: martareisalves@yahoo.com.br. ${ }^{2}$ Nurse, PhD in Nursing, Professor of the Department of Health and Post-graduate Studies, Master's Level, Nursing and Health at the State University of Southwest Bahia. E-mail: albavilela@gmail.com. ${ }^{3}$ Nurse, Doctoral of the Post-graduate Program in Nursing of the Federal University of Bahia. Professor, Department of Health State University of Southwest Bahia. E-mail: andreasouza_75@hotmail.com. ${ }^{4}$ Nurse, Master's Post-graduate Program in Nursing and Health, State University of Southwest Bahia. Fellow of the Coordination of Improvement of Higher Education Personnel (CAPES). E-mail: doane.ef@hotmail.com. Nurse, Master in Nursing, Professor of the Department of Health, State University of Southwest Bahia. E-mail: edmeiameira@yahoo.com.br. ${ }^{6}$ Nurse, Master's of the Post-graduate Program in Nursing, Federal University of Bahia. Scholarship Student of the Coordination for Improvement of Higher Education Personnel (CAPES). E-mail: alinecte@hotmail.com.
}

R. pesq.: cuid. fundam. online 2013. abr./jun. 5(2):3667-76 


\section{INTRODUCTION}

Depression is a disorder of affective area of multifactorial origin, which negatively affects the quality of life of the elderly increases the risk of morbidity and mortality, causes growth in the use of health services, as well as burdens families and caregivers. $^{1-2}$

Studies show that depression is one of the most prevalent mental disorders in the elderly, due to functional changes in the central nervous system of continuous losses of loved ones, social isolation and crippling diseases - factors common in this age group and that favor the development of depression. Besides these factors, longevity comes the most feared of losses, of life itself (near death), which makes older people more vulnerable to depression.

It is noteworthy that the frequency of depression varies according to the characteristics of the study population. Thus, it is estimated that the prevalence of depression among the elderly living in the community is between $14 \%$ and $52 \%$, but among those who are institutionalized, these rates drop to $25 \%$ and $80 \%{ }^{6}$

From this perspective, in view of the prevalence of depression in the elderly population and the consequences that this disease can cause, it is vital to have a different look for this mental disorder at this stage of life that aims at the prevention, diagnosis and early intervention in order to provide an active and healthy aging.

In this scenario, an important resource that can assist healthcare professionals in preventing and coping with depression, is a social support network, since the people who compose it can act as protector and maintainer source of physical and mental health, by providing resources to the elderly - in the form of instrumental support, economic, social and emotional. ${ }^{7}$

The social support network consists of a set of significant others for the elderly, there is a R. pesq.: cuid. fundam. online 2013. abr./jun. 5(2):3667-76 reciprocal relationship. ${ }^{8-9}$ These networks can be divided into: informal, consisting of family, friends, coworkers and study, as well as community relations (neighbors, church groups, social groups, a maid) and formal, consisting of health professionals, public and private services. ${ }^{10}$

Given that social support is protective and strong influence in dealing with depression, this study aimed to describe the demographic profile of older people with depressive symptoms and the structure of their social support network on the size, composition and degree of proximity of the elderly with network components.

Given the above, this study will provide subsidies for the implementation of actions aimed at prevention and early intervention in depressive disorders, as well as provide a source of knowledge in this subject area. Furthermore, the identification of the social support network of the elderly with depressive symptoms allows healthcare professionals work in partnership with the same network in order to promote a better quality of life in this age group.

\section{METHODOLOGY}

This is a descriptive study with crosssectional quantitative approach carried out in the catchment area of a Health Unit Family JequieBA, with the 120 elderly people registered for one of the teams of that unit. It is considered one elderly person aged over 60 years, as established by the Elderly. ${ }^{11}$

This study was approved by the Research Ethics Committee of the State University of Southwest Bahia, protocol $n{ }^{\circ} 250 / 2008$. Thus, we considered the ethical and legal issues involving research with human subjects, according to Resolution $196 / 96$ of the National Health Furthermore, this study was conducted with the permission of the individuals involved, through the signing of Consent. 
Alves MR, Vilela ABA, Souza AS et al.

We established the following inclusion criteria: older adults with depressive symptoms, as evidenced from the application of the Geriatric Depression Scale Short (GDS-15), who agreed to participate voluntarily in the study and showed no cognitive impairment in the evaluation of the Mini-Mental State Examination (MMSE).

Accordingly, among the 120 patients studied, 32 were excluded, since 24 showed no depressive symptoms evidenced by EDG-15:08 had cognitive impairment. Therefore, the final sample consisted of 88 elderly people.

Data collection occurred from October to December 2010, and we used the following instruments: Short Geriatric Depression Scale (GDS-15), Mini-Mental State Examination (MMSE), a form consisting of sociodemographic questions Map Minimum Relations and configuration form the Social Support Network.

There were two home visits for elderly, previously scheduled. At first, the researchers established with the collaboration of the Community Health Agents (ACS), the first contact with the elderly in their homes, where the MMSE was used to assess cognitive function, cognitive impairment is considered below the following values scores: illiterate $=20 ; 1-4$ years of schooling $=25 ; 5-8$ years of education $=26.5 ; 9-11$

$=28$ years of education, and education for individuals with more than 11 years $=29 .{ }^{13}$

It is worth noting that elderly people without cognitive impairment $(n=112)$ were submitted to the Geriatric Depression Scale in a shorter version (GDS-15), for screening depressive symptoms. The version recommended by the Ministry of Health consists of 15 questions with dichotomous responses (yes or no). The cutoff point for identifying depressive symptom score is above 5 points, so a score between 0 and 5 is considered normal, 6-10 indicates mild depression, and 11 to 15, severe depression. Thus, of the 112 investigated elderly without cognitive R. pesq.: cuid. fundam. online 2013. abr./jun. 5(2):3667-76
Social support network...

impairment were identified 88 elderly patients with mild depressive symptoms.

On the second visit the elderly identified with depressive symptoms were administered the Map Minimum Social Relations and a structured form, developed by the researchers, which addressed the sociodemographic characteristics of the elderly, such as age, sex, marital status, education and family income .

The social support network of the elderly was assessed using the Map Minimum Social Relations (MMRS), an instrument designed by Sluzki in 1997 and adapted by Domingues, in 2000, in order to be applied to the elderly. This instrument (Figure 1) consists of three concentric circles, divided into five quadrants, which are represented in the areas of composition of relations, namely: family, friends, and community relations, relationships with the health system and labor relations / study.

The MMRS is a central point that represents the informant, and network members are represented in their respective circles and quadrants. The circles represent the degree of closeness of relationships, and the closest to the informant is intimate relations; intermediate, relations with less closeness, and the external, distant relations. ${ }^{15}$

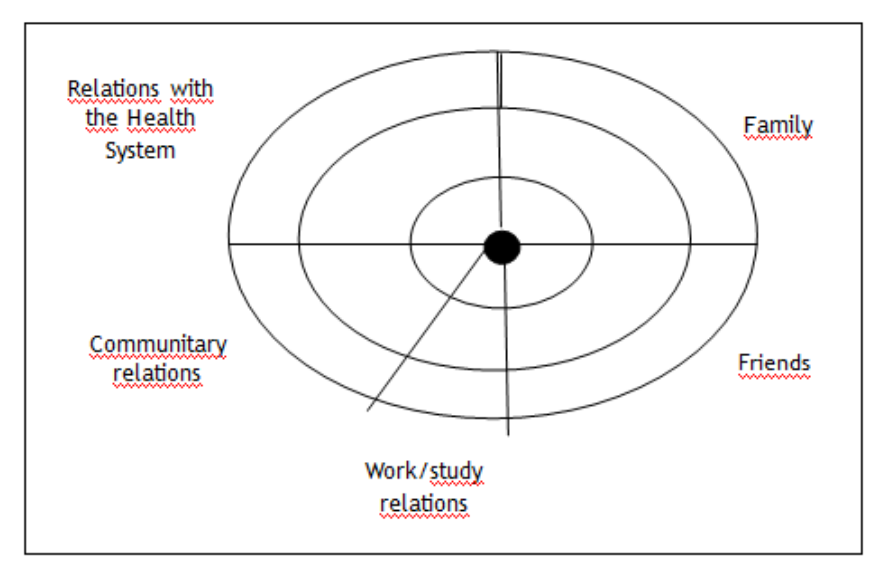

Figure 1: Map minimum of social relations Source: Adapted from Sluzki (1997) by Domingues (2000)

For complete information about the network configuration, we also applied a form 
Alves MR, Vilela ABA, Souza AS et al.

that indicates the degree of kinship of the people present in the quadrant "family", the nature of relationships in the quadrant "community" (neighbors, church groups and coexistence groups), the category of health professionals in the quadrant "relationships with the health care system" and the location of individuals in the network (inner circle, intermediate or external).

In possession of instruments filled, was created a database in Microsoft Excel 2007, with data organized in tables and subjected to descriptive analysis, through absolute frequencies, percentages, means and standard deviations.

\section{RESULTS AND DISCUSSION}

\section{Sociodemographic profile of older people with depressive symptoms}

The study results showed, according to the criteria proposed by the GDS-15, a prevalence of depressive symptoms in $78.6 \%$ of the elderly population investigated without cognitive impairment $(n=112)$.

Thus, one can observe that this index shows up higher than that found in other studies of elderly residents in other communities, such as the study of Fernandes et al5 who found a $52 \%$ occurrence of depressive symptoms among elderly enrolled in a Family Health Unit of the city of João Pessoa.

It's worth noting that differences in the prevalence of depression among studies may be attributed to possible socioeconomic differences. Furthermore, research shows that factors such as poor social conditions, low income, lack of social activities and social isolation directly reflect the increased chance of emergence of depression.

In this sense, a factor that favors the occurrence of the high prevalence of depressive symptoms in this study relates to the venue of the trial, which is in a suburb where there are scarce
Social support network...

social resources, high unemployment, low income and lack of activities related to social and leisure occupation for seniors. This fosters social isolation, which is one of the predisposing factors for depression.

With regard to sociodemographic data of the 88 older adults with depressive symptoms (Table $1)$, there was a predominance of females $(72.7 \%)$, which is consistent with the results of the Synthesis of Social Indicators of 201,018, showing a feminization of aging. This is a reflection of the higher life expectancy of women, which occurs because they are less exposed to risk factors such as traffic accidents and work, the lower prevalence of smoking and alcohol consumption and seek services health more frequently than men. ${ }^{19-20}$

It is noteworthy that the prevalence of depressive symptoms have been associated with increased frequency to females, since, due to the greater longevity of women, they are exposed for longer periods of chronic diseases, widowhood and loneliness, which implies the possibility of depressive disorder. ${ }^{21}$

One factor that favors the occurrence of depression in elderly women is that, with advancing age and the arrival of menopause, there is a reduction of female hormones, especially estrogen - because it has any function favor the noradrenergic and serotonergic neurotransmission, the lowest availability of this hormone facilitates the occurrence of mood disorders, including depression. $^{22}$ 
Alves MR, Vilela ABA, Souza AS et al.

Table 1 - Distribution of the elderly $(n=88)$ according to sociodemographic variables - Jequie, Bahia, 2010.

\begin{tabular}{|c|c|c|}
\hline Sociodemographic Variables & Frequence & Percentual \\
\hline \multicolumn{3}{|l|}{ Gender } \\
\hline Female & 64 & 72,7 \\
\hline Male & 24 & 27,3 \\
\hline \multicolumn{3}{|l|}{ Age } \\
\hline $60-69$ years old & 37 & 42 \\
\hline & 29 & 33 \\
\hline 80 or older & 22 & 25 \\
\hline \multicolumn{3}{|l|}{ Marital status } \\
\hline Married & 44 & 50 \\
\hline Divorced & 10 & 11,4 \\
\hline Widower & 23 & 26,1 \\
\hline Single & 11 & 12,5 \\
\hline \multicolumn{3}{|l|}{ Scholarity } \\
\hline Illiterate & 71 & 80,6 \\
\hline Literate & 17 & 19,4 \\
\hline \multicolumn{3}{|l|}{ Family income } \\
\hline$<=1$ minimum salary ${ }^{*}$ & 48 & 54,5 \\
\hline$>1$ minimum salary & 40 & 45,5 \\
\hline
\end{tabular}

Source: Survey data, 2010.

* The minimum wage rate at the collection period was $\mathrm{R} \$ 465,00$

In terms of age, there was a predominance of elderly aged 60 and 69, which corresponded to $42 \%$. This information is in line with Brazilian standards, as evidenced by the report Summary of Social Indicators of 201,018, according to which people between 60 and 69 years have a greater representation within the senior segment.

In the present study, it was revealed that the "younger seniors" had more depressive symptoms than the group of "older elderly". Thus, we can see a similarity with the study Lambert ${ }^{23}$, which states that people from older generations are less likely to develop depression than those of the current generation.

However, other studies $5,21,24$ showed an association between advanced age and increased incidence of depression, which may be related to the fact that, with advancing age, there is a higher incidence of events related to losses impairment of health, death of family members, loss of social and labor - which generates a predisposition to the occurrence of depressive symptoms. Thus, it appears that there is no consensus in the research regarding the association between depression and age.
Social support network...

With regard to marital status, it can be observed that although $50 \%$ of the elderly are living with spouse, married depressive symptoms, which may be related to the quality of relationships between spouses. This result has to be compatible with the study of Maciel and Guerra $^{24}$, in which $55.8 \%$ of older people with depressive symptoms were married.

Another half of older adults with depressive symptoms lived without a partner (a), with the prevalence among these elderly widowed (26.1\%). This is justified by the fact that the elderly widow become more vulnerable to the occurrence of depressive, since stressful events and negative, as the loss of a spouse, require the need for adjustment and can, moreover, be the starting point to psychic breakdown, favoring the development of depressive symptoms.

With regard to schooling, $80.6 \%$ were illiterate. This fact can be explained because of those who, today, are 60 years or older, have lived in a time when access to education was restricted. It is believed that another factor favoring the low education group in regards elderly female predominance; since, in traditional societies, women were prevented from studying due to the cultural patterns that determined that these fit the responsibility just take care of the children and household chores.

Studies $^{5,17,21}$ indicate the low level of education as an important predictor of depression in the elderly, since older people with more education have better access to medical care, the activities involved in stimulating cognitive and mental functions, and have greater level of social participation - important factors in preventing depressive disorders.

Regarding family income, 54.5\% of households of the elderly lived with up to 1 minimum wage. Thus, one can see that the participants in the study had low income, most of which depended financially on retirement

R. pesq.: cuid. fundam. online 2013. abr./jun. 5(2):3667-76 
Alves MR, Vilela ABA, Souza AS et al.

pensions and smallest values, which can significantly compromise their survival. Furthermore, it was found that the incomes of the elderly in the study were generally intended to expenditure on food and medicines, and, in most cases, were the only source of income for the whole family.

It is noteworthy that the low purchasing power is one of the predisposing factors for the occurrence of depressive symptoms, as demonstrated in the study Alvarenga, which revealed that those with low income group had 1.86 greater chance of depressive symptoms compared to those with greater power purchasing.

Given the above, it is clear that information on the demographic profile of older adults with depressive symptoms are essential to identify risk factors associated with the development of depressive, enabling the planning of actions aimed at preventing and coping with this disease.

\section{Social support of older people with depressive symptoms}

The social support network can be evaluated as to their structural characteristics, including size, composition and levels of closeness of relationship between the elderly and the components of your network. This network is recorded in the form of Minimum Map of Social Relations (MMRS), which includes all individuals considered significant for the elderly.

With respect to the network size, which corresponds to the total of those mentioned for the elderly, it can be seen (table 2) that the network of social support 88 elderly patients with depressive symptoms consists of a total of 807 individuals, mean of 9.2 persons / seniors $($ standard deviation $=1.02)$.

It's worth noting that, in addition to assessing the size of the network, it is essential to classify it according to the number of elderly
Social support network...

persons named in the first round by the proximity of the MMRS, considered the circle of intimate relationships, since this type relationship directly affects the health status of the elderly, by providing resources (emotional, economic and material) needed to maintain their quality of life and well-being. ${ }^{10}$

In this context, Alvarenga ${ }^{10}$ classifies the network as small as two people in the first round; net average, between three and five people in that circle, and up to six people, large network. It should be noted that a very large network of connections and tenuous proves ineffective, since people assume that the other subjects that make up the network will do something that is necessary and, therefore, often nobody does. In very small networks, the problem is in function overloading, which can generate stress in its members. ${ }^{8}$

From this perspective, it can be seen (table 2 ) that the social support of elderly people with depressive symptoms consisted of average size, since the close relationships or subject is closer to approximately four. Please note that, as mentioned earlier, there are indications that the medium-sized networks are more effective than small or too numerous. ${ }^{8}$

This result is extremely important because it is believed that people who are part of the intimate level of closeness can assist the elderly in solving problems and, as a result, serve as support in situations of confrontation of negative events and, somehow, assist in preventing the development of depressive disorders. ${ }^{26}$

Table 2 - Frequency distribution, mean and standard deviation of the number of members $(n=807)$ of social support of older people with depressive symptoms, according to the degrees of proximity (inner, intermediate and outer) - Jequie-BA, 2010.

\begin{tabular}{lrrr}
$\begin{array}{l}\text { Level of proximity of the } \\
\text { elderly with the staff }\end{array}$ & Frequency & Average & Standard Deviation \\
\hline Closed & 389 & 4,4 & 1,02 \\
Intermediate & 297 & 3,4 & 1,36 \\
Extern & 121 & 1,4 & 1,43 \\
\hline
\end{tabular}

Source: Survey data, 2010.

R. pesq.: cuid. fundam. online 2013. abr./jun. 5(2):3667-76 
Alves MR, Vilela ABA, Souza AS et al.

Regarding the composition of the network (table 3), which refers to the distribution of its components according to the categories family, friends, community members, health professionals and people who are part of the work / study, it was found that people's comprise the largest family network frequency of study subjects (34.8\%). Further, they emphasized the participation of friends $(22.3 \%)$ of people in the community $(22.3 \%)$ and health professionals (19.9\%).

Given the above, it becomes clear that the family is the social partners more frequently, which demonstrates the importance of this as support for the elderly, as it is in family life that the old builds relationships that constitute its primary support base to confront the daily difficulties - which contributes to the promotion and maintenance of emotional health of elderly, preventing the development of depressive disorders.

The family is assigned a major role in preserving the physical and emotional integrity of its members, providing your wellbeing. The family is present in day-to-day life of the elderly, having to deal with the aging process and the problems that this can develop. ${ }^{27}$ Thus, we note the important role of the family in providing care to the elderly.

Among the family members were cited more often the children (57.4\%), followed by other relatives $(42.6 \%)$ - these include spouse, son, daughter, niece and sister. Thus, the figure of children represents an important source of support, which reinforces a social norm that is transmitted from generation to generation, which states that parents take care of the children and then the children fit the commitment to care for their parents in old age.
Social support network...

Table 3 - Distribution of frequency and percentage of the number of members $(n=807)$ of social support of older people with depressive symptoms, according to the categories of family, friends, community, health professionals and people who are part of the work / study - Jequie, Bahia, 2010.

\begin{tabular}{lcc}
\hline Categories of the net components & Frequency & Percentual \\
\hline Family & 281 & 34,8 \\
& & \\
Friends & 180 & 22,3 \\
& & \\
Community & 180 & 22,3 \\
Neighbors & 150 & 18,6 \\
Church members & 30 & 3,7 \\
& & \\
Professionals of Health & 161 & 19,9 \\
Communitary Health Agents & 67 & 8,3 \\
$\quad$ Nurse & 54 & 6,7 \\
Physician & 40 & 4,9 \\
& & \\
Members part of the work or study & 05 & 0,7 \\
\hline
\end{tabular}

Source: survey data, 2010.

In this study, the friends also represented an important source of social support. This fact is beneficial, since the relationship with friends is a subjective and affective relationship that extends beyond the social spaces, being relevant for the elderly in maintaining feelings of well-being, reducing loneliness and providing emotional support in moments of crisis, which help to prevent depression.

Another component of social support was appointed by elderly individuals belonging to the community, which were represented by neighbors (18.6\%) and church members (3.7\%). The relationship with the elderly neighbors is favored by geographical proximity and frequent contact, which means that, over time, among them there is a sense of friendship, solidarity and a mutual sharing of daily events, enabling neighbors act as a reference when seniors need help.

Members of the church were also cited by the elderly, which demonstrates that the church is an environment conducive to maintaining or adding new relationships, providing a social interaction of great importance and significance for the elderly. The church helps seniors cope times of crisis and illness and thus plays an important role in coping with depressive disorders.

With regard to health professionals, the Community Health Agents (ACS) was the most

R. pesq.: cuid. fundam. online 2013. abr./jun. 5(2):3667-76 
Alves MR, Vilela ABA, Souza AS et al.

frequently cited by the elderly $(8.3 \%)$, followed by nurses (6.7\%) and medical (4.9\%).

The predominance of ACS as the main component of formal social support network of the elderly is justified, perhaps, by the fact that one of his activities recommended by the Ministry of Saúde29 consists in monitoring families through home visits, which favors greater contact with the elderly, as well as providing the opportunity to talk and to strengthen the bond with them.

Thus, within the multidisciplinary team that makes up the Family Health Strategy (FHS), the ACS has been shown to be the main link between this and the community, providing the approach of health to the home context. However, the proposal that FHS is not only the ACS, but all the professionals that comprise establish bonds of commitment and coresponsibility with the population.

In this sense, knowing the structure of the social network of the elderly is crucial, as it provides meaningful information to improve the planning of care for the elderly and, thus, promoting a better quality of life in old age.

\section{CONCLUSION}

The results showed an elderly population was predominantly female, aged between 60 and 69 years, low income and education. One fact that caught my attention was the high prevalence of depressive symptoms (78.6\%) in the elderly investigated, as evidenced by the application of the GDS-15. It is a sobering fact, since depression affects the quality of life of the elderly, increases the risk of clinical morbidity and mortality.

The high rate of depression among the elderly studied reflects the importance of diagnosis and treatment of this disorder. Therefore, health professionals should be trained to recognize the symptoms of depression through the GDS-15, as this is recognized as a tool for R. pesq.: cuid. fundam. online 2013. abr./jun. 5(2):3667-76
Social support network...

quick and useful resource for the identification of depressive symptoms, enabling early interventions and effective.

Regarding the structure of the social support network of older people with depressive symptoms, total persons named by them was 807 , with an average of 9.2 persons / elderly. In assessing the degree of proximity of the elderly members of your network, it was found that prevailed intimate relationships, registering a total of 389 components at this level.

In the analysis of the quadrants, the results showed that family members representing the social partners more frequently, which demonstrates the importance of this to support the elderly. The friends formed the second largest network of support, followed by members of the community, and among healthcare professionals, CHWs were the most cited.

The results revealed that an important resource to be used by health professionals to prevent and cope with depression is to understand the social support of the elderly, since it can act as a protective agent against the incidence of depression, by providing for seniors resources in the form of emotional, instrumental, physical and economic, which are essential to making the individual capable of facing depressive disorder.

Thus, it is necessary that health professionals act in partnership with the components of social support network to implement actions that promote the prevention and reduction of depressive symptoms in old age, and thus improve the quality of life of this age segment.

\section{REFERENCES}

1. Carreira L, Botelho MR, Matos PCB, Torres MM, Salci MA. Prevalência de depressão em idosos institucionalizados. Rev enferm UERJ. 2011; 19(2): 268-73. 
Alves MR, Vilela ABA, Souza AS et al.

2. Alvarenga MRM, Oliveira MAC, Faccenda 0 , Cerchiari EAN, Amendola F. Sintomas depressivos em idosos assistidos pela estratégia saúde da família. Cogitare Enferm. 2010 abr/jun; 15(2): 217-24.

3. Rebello PMP, Leite SP, Mouallem ARE, Lisboa ACV, Marcelino AR, Bernardo BS. Suspeição de depressão segundo escala geriátrica em uma Equipe da estratégia saúde da família. Rev APS. $2011 \mathrm{jul} / \mathrm{set} ;$ 14(3): 313-18.

4. Beltrão IN, Silva LM, Alves MSCF, Moreira MASP, Mendes F, Targino RRB. Symptomatology the depression in elderly attended from basic health units. R pesq cuid fundam online $2011 \mathrm{dez}$; [citado 20 ago 2012]; (Ed.Supl.):1-8. Disponível em: ttp://www.seer.unirio.br/index.php/cuidadofund amental/issue/view/79.

5. Fernandes MGM, Nascimento NFS, Costa KNFM. Prevalência e determinantes de sintomas depressivos em idosos atendidos na atenção primária de saúde. Rev Rene. 2010; 11(1): 19-27.

6. Canineu PR. Depressão no idoso. In: Papaléo Netto M. Tratado de gerontologia. $2^{a}$. ed. São Paulo: Atheneu; 2006.

7. Costa AG, Ludemir AB. Transtornos mentais comuns e apoio social: estudo em comunidade rural da Zona da Mata de Pernambuco, Brasil. Cad Saúde Pública. 2005; 21(1): 73-9.

8. Sluzki CE. A rede social na prática: alternativas terapêuticas. São Paulo: Casa do Psicólogo; 1997.

9. Neri AL. Redes de Suporte Social. In: Neri AL. Palavras Chaves em Gerontologia. $2^{\text {a }}$ ed. Campinas (SP): Editora alínea; 2005.

10. Alvarenga MRM, Oliveira MAC, Domingues MAR, Amendola F, Faccenda O. Rede de suporte social do idoso atendido por equipes de Saúde da Família. Ciênc saúde coletiva. 2011; 16(5): 2603611.

11. Brasil. Lei $n^{\circ} 10.741$, de 01 de outubro de 2003. Dispõe sobre o Estatuto do Idoso e dá outras providências. Diário Oficial da República Federativa do Brasil. 2003.
Social support network...

12. Brasil. Ministério da Saúde. Conselho Nacional de Saúde. Comissão de Ética em Pesquisa. Resolução no 196, de 10 de outubro de 1996: aprova as diretrizes e normas regulamentadoras de pesquisa envolvendo seres humanos. Rev bioét. 1996; 4(2); 15-25.

13. Brucki SMD, Nitrini R, Caramelli $P$, Bertolucci PHF, Okamoto IH. Sugestões para o uso do miniexame do estado mental no Brasil. Arq NeuroPsiquiatr. 2003; 61(3): 777-81.

14. BRASIL. Ministério da Saúde. Secretaria de Atenção à Saúde. Departamento de Atenção Básica. Envelhecimento e Saúde da pessoa idosa. Brasília: Ministério da Saúde; 2006.

15. Domingues MARC. Mapa Mínimo de relações: Adaptação de um instrumento gráfico para a configuração da rede de suporte social do idoso [dissertação]. São Paulo (SP): Universidade de São Paulo, Departamento de Saúde Pública; 2000.

16. Lima MTR, Silva RS, Ramos LR. Fatores associados à sintomatologia depressiva numa corte urbana de idosos. J Bras Psiquiatr. 2009; 58(1): 17.

17. Irigaray TQ, Schneider RH. Prevalência de depressão em idosas participantes da Universidade para a Terceira Idade. Rev Psiquiatr. 2007; 29(1): 19-27.

18. Instituto Brasileiro de Geografia e Estatística (IBGE). Síntese de Indicadores Sociais 2010. Disponível em:

http: / /www.ibge.gov.br/home/estatistica/popula cao/condicaodevida/indicadoresminimos/sintesein dicsociais2010/SIS_2010.pdf >. Acesso em: 10 de jan. 2012.

19. Pliger C, Menon MH, Mathias TAF. Características sociodemográficas e de saúde de idosos: contribuições para os serviços de saúde. Rev Latino-Am. 2011; 19(5): 1-9.

20. Madureira VSF, Peliser SR, Beltrame V, Stamm M. Mulheres idosas falando sobre envelhecer: subsídios para a promoção da saúde. Rev Min Enferm. 2008 jan./mar; 12(1): 17-26.

R. pesq.: cuid. fundam. online 2013. abr./jun. 5(2):3667-76 
Alves MR, Vilela ABA, Souza AS et al.

21. Leite VMM, Carvalho EMF, Barreto KML, Falcão

IV. Depressão e envelhecimento: estudo nos participantes do Programa Universidade Aberta à Terceira Idade. Rev Bras Saúde Matern Infant. 2006; 6(1): 31-8.

22. Veras $A B$, Nardi $A E$. Hormônios sexuais femininos e transtornos do humor. Jornal Bras Psiquiatria. 2005; 4(1): 57-68.

23. Lambert K. Tão fácil que até deprime. Rev Mente e Cérebro. 2008 nov; 2(1): 36-45.

24. Maciel ACC, Guerra RO. Influência dos fatores biopsicossociais sobre a capacidade funcional de idosos residentes no nordeste do Brasil. Rev Bras Epidemiol. 2006; 10(2): 178-89.

25. Pinho $M X$, Custódio O, Makdisse $M$. Incidência de depressão e fatores associados em idosos residentes na comunidade: revisão de literatura. Rev Bras de Geriatr Gerontol. 2009; 12(1): 123-40. 26. Griep RH, Chor D, Faerstein E, Werneck G, Lopes C. Validade de constructo de escala de apoio social do Medical Outcomes Study adaptada para o português no Estudo Pró-Saúde. Cad Saúde Pública. 2005; 21(3): 703-14.

27. Lemos N, Medeiros, SL. Suporte social ao idoso dependente. In: Freitas EV, Py L, Neri AL, Cançado FAXC, Gorzoni ML, Doll J. Tratado de Geriatria e Gerontologia, $2^{\mathrm{a} e d}$. Rio de Janeiro: Guanabara Koogan; 2002.

28. Sommerhalder C, Goldstein LL. O papel da espiritualidade e da religiosidade na vida adulta e na velhice. In: Freitas EV, Py L, Neri AL, Cançado FAXC, Gorzoni ML, Doll J.Tratado de Geriatria e Gerontologia, $2^{\mathrm{a}}$ ed. Rio de Janeiro: Guanabara Koogan; 2006.

29. Brasil. Portaria $n^{\circ} 2.488$, de 21 de outubro de 2011. Aprova a Política Nacional de Atenção Básica, estabelecendo a revisão de diretrizes e normas para a organização da Atenção Básica, para a Estratégia Saúde da Família (ESF) e o Programa de Agentes Comunitários de Saúde (PACS). Diário Oficial da República Federativa do Brasil, 2011.

R. pesq.: cuid. fundam. online 2013. abr./jun. 5(2):3667-76
Social support network...

30. Oliveira EM, Spiri WC. Programa Saúde da Família: a experiência de equipe multiprofissional. Rev Saúde Publica. 2006; 40 (4): 727-33.

Received on: 26/09/2012

Required for review: No

Approved on: 02/03/2013

Published on: 01/04/2013 